'We lay gasping for some time. When we recovered our breath, Shaw said very coolly: "That was a near thing", and went off to fetch his sandshoes, which were drying where our swim began. When he came back I asked him whether visions of his past life had come before him, as they say the drowning have them. He shook his head. "Nor I-" I said.'

\title{
Swimming: III
}

\section{LILLAH MCCARTHY}

From Lillah McCarthy, Myself and My Friends (London: Thornton Butterworth, 1933) p. 88. Lillah McCarthy's memories are centred on the decade preceding the First World War.

Shaw is a very strong swimmer. I am not. Many times he would give me lessons. When he is teaching some exercises or art, away from the theatre, he is both patient and kind. He would tell me to put one hand upon his shoulder and just swim, on and on. We would find ourselves well out to sea. Then a change would come over Shaw, a sea change. He is vigorous on land but when he is swimming in the sea, he becomes for once tranquil. He would say to me as we swam: 'We are in another world'. If I were afraid when I saw the land slipping farther and farther away, he would say: 'Have no fear, Lillah, gently and slowly does it.'

\section{Swimming: IV}

\section{LAWRENCE LANGNER}

From Lawrence Langner, 'The Sinner-Saint as Host: Diary of a Visit to GBS at Stresa', Saturday Review of Literature (New York), 22 July 1944. When Langner and his wife Armina stayed with the Shaws at the Regina Palace Hotel, Stresa, in August 1927, they were woken the first morning at seven by Shaw asking them to swim with him. 